\title{
Beyond Pedagogical Content Knowledge: The Importance of TPACK for Informing Preservice Teacher Education in Australia
}

\author{
Glenn Finger ${ }^{1}$, Romina Jamieson-Proctor ${ }^{2}$, and Peter Albion ${ }^{2}$ \\ ${ }^{1}$ Griffith University, Gold Coast campus, Queensland, Australia \\ G.Finger@griffith.edu.au \\ ${ }^{2}$ University of Southern Queensland, Queensland, Australia \\ Romina.Jamieson-Proctor@usq.edu.au, \\ Peter.Albion@usq.edu.au
}

\begin{abstract}
Since the emergence of computers in schools during the 1980's, there have been considerable developments by education systems and schools to develop policies and expectations for the use of information and communication technologies (ICT) to enhance learning and teaching. These have not always translated into practice, which has resulted in a focus on the need for improvements in preservice teacher education programs and professional development of practising teachers. This paper starts from the premise that most teacher education have been constrained by using Pedagogical Content Knowledge (PCK) developed by Shulman [1] [2] prior to the dynamic technological changes enabled by the Internet. The authors present the case for the importance of Technological Pedagogical Content Knowledge (TPACK) [3] [4]. Subsequently, the paper provides guidance for auditing the TPACK capabilities of teacher education students through the presentation of an instrument developed, and provides a summary of some of the findings of a study undertaken using that instrument.
\end{abstract}

Keywords: Technological Pedagogical Content Knowledge, TPACK, Preservice Teacher Education, Professional Standards, Information and Communication Technologies.

\section{Introduction - Moving beyond PCK to TPACK to Design Teacher Education Programs}

Preservice teacher education programs have the responsibility for preparing future teachers who are likely to be teaching their students in a world characterised by ongoing technological changes. How well are we designing our preservice teacher education students for present and future technological contexts? How are they currently designed? What guidance can be provided for improving their design?

Most teacher education programs in Australia have been designed using Shulman's Pedagogical Content Knowledge (PCK) [1] [2]. This paper argues that this is inadequate in building the professional capabilities of future teachers to use ICT to enhance 
learning and teaching in the 21st Century. The paper, in providing advice to move beyond PCK, draws upon the more contemporary conceptualization of Technological Pedagogical Content Knowledge (TPCK), now known as TPACK [3] [4] [5] [6]. Our position aligns with that of Koehler, Mishra and Yahya [5] who appropriately indicate that:

...intelligent pedagogical uses of technology require the development of a complex, situated form of knowledge we call Technological Pedagogical Content Knowledge (TPCK). At the heart of TPCK is the dynamic, transactional relationship between content, pedagogy and technology. (p. 741)

Throughout this paper, we use TPACK which has the connotation of Technological Pedagogical Content Knowledge being 'the total package' for teaching in the 21st Century. This paper provides guidance for undertaking an audit of the TPACK capabilities of teacher education students through a summary of the instrument developed by the authors. It provides some insights into the findings of a study undertaken by the authors using that instrument. Finally, we encourage others involved in teacher education to take up this approach, and design teacher education programs needed to develop future teachers' TPACK capabilities.

\section{Expectations, Conceptualising TPACK and Stages of Preservice Teacher Education Programs}

The following sections provide a discussion of the expectations for teachers, and identifies that the importance of TPACK is not yet well understood.

\subsection{Expectations}

Most teacher education programs in Australia have been designed by taking into account PCK, which Shulman [2] described as "the special amalgam of content and pedagogy that is uniquely the province of teachers, their own special form of professional understanding" (p. 8). Shulman's work [1] is reflected in many of the current conversations which the authors, all teacher educators in Universities in Queensland, a State in Australia have been engaged in relating to Government and public perceptions of literacy, numeracy and science teaching in primary schools in that State. The review, A Shared Challenge: Improving Literacy, Numeracy and Science Learning in Queensland Primary Schools [9], resulted in five recommendations, with the first recommendation being the preregistration testing of primary teacher graduates. Masters [9], in his report, articulated concerns about how well prepared teachers were in terms of their PCK.

A search throughout the report by Masters [9] reveals numerous references to 'content knowledge', 'pedagogical knowledge', and 'pedagogical content knowledge'. There were no references made to TPACK, though some mention is made in relation to the Queensland College of Teachers Professional Standards [7] for teachers requiring that teachers need to know and understand "ways of identifying, evaluating and selecting teaching, learning and assessment strategies, resources and technology" (p. 67) and that: 
...the challenge of ensuring that every student completes primary school with the knowledge, skills and attitudes required for success in secondary school suggests that entirely new solutions will be required to some longstanding problems. Technology is likely to play a part in some of these solutions (p. 93).

While it is not the purpose of this paper to critique the report by Masters [9], we note that his report makes no contribution to the task of the Assessment and Teaching of 21st Century Skills (ATC21S) project [10] which aims to measure skills needed in the 21st Century, such as cross disciplinary, creative, adaptive and problem-solving skills as well as the ability to work cooperatively [10]. Involving Australia, Finland, Portugal, Singapore and Britain, the approach by ATC21S is further supported by McGaw [11] who stated that, "change on a global scale is required to equip students of today with the skills they need to succeed in the workforce of tomorrow" (p. 1). McGaw highlights that this has been elusive to date, as "We hoped to add information and communications technology (ICT) competence in PISA 2006 but did not succeed...We all need now to work together to advance assessment practice" (p. 1).

Furthermore, Finger [12] notes that, while there has been a growing focus on TPACK, particularly in the United States of America, TPACK is only emerging in Australia in conversations about teacher education program design. This paper attempts to play a role in adding to these early conversations to inform teacher education program design.

\subsection{Conceptualising TPACK Knowledge and Preservice Teacher Education Programs}

Mishra and Koehler [13] explain how TPACK enables teacher education students to develop understanding about how the selection of technologies can lead to good teaching with technology as one of "three core components - content, pedagogy and technology, and the relationships between them" (pp. 11-12). Moreover, TPACK incorporates the importance of context, and "solutions require nuanced understanding that goes beyond the general principles of content, technology and pedagogy" (p. 23). We suggest that where ICT initiatives have failed, there has not been any TPACK conceptualization informing the thinking, design and implementation. In many instances, teachers tend to find the professional development focused on technological knowledge through introducing them to new hardware or software applications, without considerations of context, pedagogy and content.

We agree with the assertion by Lee and Gaffney [14] that we need to move from a paper-based Industrial Age model of schooling to a digitally based paradigm more appropriate for an Information Age model of schooling. In attempting to explain teacher adoption of digital technologies, stages of teacher development have been proposed by Newhouse et al. [15] who suggest that teachers might move through stages of inaction, investigation, application, integration and transformation. Table 1 presents a synthesis of Lee and Gaffney's [14] characteristics of traditional paperbased and digitally-based paradigms, and Newhouse et al.'s [15] stages of teacher development, and teacher education programs. 
Table 1. Stages of teacher development, stages of school development and TPACK (adapted from [16], pp. 220-221)

\begin{tabular}{|c|c|c|}
\hline $\begin{array}{l}\text { Stages of Teacher } \\
\text { Development } \\
\text { (adapted from [15]) }\end{array}$ & $\begin{array}{l}\text { Stages of School } \\
\text { Development } \\
\text { (adapted from [14]) }\end{array}$ & $\begin{array}{l}\text { Preservice Teacher } \\
\text { Education Programs } \\
\text { (adapted from [7]) }\end{array}$ \\
\hline Inaction & $\begin{array}{l}\text { Traditional Industrial Age } \\
\text { model of school organisation }\end{array}$ & $\begin{array}{l}\text { Focus on content } \\
\text { Directed instruction } \\
\text { Teacher-centred }\end{array}$ \\
\hline Investigation & $\begin{array}{l}\text { Early stages of understanding } \\
\text { of the Information Age }\end{array}$ & $\begin{array}{l}\text { Focus on pedagogy and content } \\
\text { Some interest in using ICT }\end{array}$ \\
\hline Application & $\begin{array}{l}\text { Exploration of digital } \\
\text { technologies to enhance } \\
\text { learning within existing } \\
\text { curriculum and school } \\
\text { organisation }\end{array}$ & $\begin{array}{l}\text { Focus on pedagogy and content } \\
\text { Courses included in programs } \\
\text { with focus on learning about ICT }\end{array}$ \\
\hline \multicolumn{3}{|c|}{ Critical Use Border } \\
\hline Integration & $\begin{array}{l}\text { Schools becoming digital } \\
\text { schools - digital take-off; e.g. } \\
\text { whole adoption of IWBs, } \\
\text { classroom Internet connectivity, } \\
\text { interoperability }\end{array}$ & $\begin{array}{l}\text { Focus on technology, pedagogy } \\
\text { and content } \\
\text { Courses included in programs } \\
\text { which focus on learning with ICT }\end{array}$ \\
\hline Transformation & $\begin{array}{l}\text { Networked school communities, } \\
\text { incorporating learning within } \\
\text { and beyond the place called } \\
\text { school - including home-school } \\
\text { nexus and school connecting } \\
\text { with communities }\end{array}$ & $\begin{array}{l}\text { TPACK framework is fully } \\
\text { embraced throughout the entire } \\
\text { program design and } \\
\text { implementation } \\
\text { Graduates demonstrate TPACK } \\
\text { capabilities }\end{array}$ \\
\hline
\end{tabular}

\section{Summary of a Study to Audit the TPACK Capabilities of Preservice Teacher Education Programs}

The authors have conducted various studies to inform program and teacher development [17] [18] [19]. The study summarized in the following sections aimed to undertake an audit of final year students at the two Universities within which they work.

\subsection{Aim and Significance of the Study}

The central question which this audit sought to answer was - How well are our teacher education programs preparing graduates to have TPACK capabilities? The significance of the study relates to the need for future teachers to have the TPACK capabilities which enable them to enhance and transform learning and teaching by having the necessary technological, pedagogical and content knowledge. This begs the questions - how can we know they have these TPACK capabilities? How can we measure these?

These continue to be early days of research using TPACK as a framework. Recent studies include those by Sahin, Akturk and Schmidt [20] and Terpstra [21]. Sahin et al. [20] found that TPACK positively affected preservice teacher education students' vocational self-efficacy. Terpstra [21], among her findings, reported that the preservice 
teachers whom she studied demonstrated more Technological Knowledge than Technological Pedagogical Knowledge and Technological Pedagogical Content Knowledge. Interestingly, Terpstra [21] found that, while the preservice teacher education students used digital technologies in their daily lives, they did not connect this Technological Knowledge with their own teaching. While there is a growing list of TPACK research occurring, a thorough search revealed only one Australian study published by Holmes [22] which investigated the lesson activities developed by a 13 final year undergraduate secondary mathematics pre-service teachers. The study reported that the pre-service teachers were able to plan effectively to integrate IWB features within their mathematical lessons and demonstrated developing TPCK as a result.

Drawing upon the TPACK conceptualisation proposed by Mishra and Koehler [13] as the theoretical framework to guide this audit, this study is significant as being thirst Australian study of its kind, in relation to adding to our knowledge about TPACK capabilities of future teachers. The findings can be used as the basis for informing the design of teacher education programs.

\subsection{Research Methodology and Demographic Information of Participants}

The development of this TPACK Confidence Survey included aspects from previously validated instruments including the ICT Audit Survey [23] and the Learning with ICT: Measuring ICT Use in the Curriculum instrument [25]. The instrument was effectively administered online using Lime Survey. Demographic information was sought, and indicators were included which reflected those expected by the Department of Education and Training in Queensland in their ICT Certificate level of the Smart Classrooms Professional Development Framework [24].

Ethics approvals were obtained from both Universities involved in the study. Responses were obtained from 345 final year preservice teacher education students from two Queensland universities - one being a Metropolitan University and the other being a Regional University. Table 2 displays the demographic information of those studied.

Table 2. Demographic information of final year students - Gender, University Attended, and Age $(\mathrm{N}=345)$

\begin{tabular}{|lrr|}
\hline & Number & \% \\
\hline Gender: & 273 & 79 \\
Female & 72 & 21 \\
\hline Male & $\mathbf{3 4 5}$ & $\mathbf{1 0 0}$ \\
\hline Total & & \\
\hline University Attended: & 199 & 57.7 \\
The Metropolitan University & 146 & 42.3 \\
\hline The Regional University & $\mathbf{3 4 5}$ & $\mathbf{1 0 0}$ \\
\hline Total & & \\
\hline Age of Pre-service Teachers: & 4 & 1.2 \\
Less than 20 years & 177 & 51.3 \\
20-29 years & 90 & 26.1 \\
30-39 years & 61 & 17.7 \\
$40-49$ years & 13 & 3.8 \\
\hline 50 + years & $\mathbf{3 4 5}$ & $\mathbf{1 0 0}$ \\
\hline Total & & \\
\hline
\end{tabular}


Table 3 below displays the student teachers' level of confidence which they reported in relation to the use of ICT with school students for teaching and learning.

Table 3. Confidence to use ICT with students

\begin{tabular}{|lcc|}
\hline Confidence to use ICT with school students for teaching and learning & Number & \% \\
\hline No confidence & 14 & 4.1 \\
Some confidence & 113 & 32.8 \\
Confident & 151 & 43.8 \\
Very confident & 67 & 19.4 \\
\hline Total & $\mathbf{3 4 5}$ & $\mathbf{1 0 0}$ \\
\hline
\end{tabular}

For students who are about to graduate, there are almost 2 out of every 5 students who reported that they had either no confidence or some confidence. This is a disturbing finding, as confidence might be expected to reflect the students' perceptions of their capabilities. The following findings reported in this paper explore this further.

\section{Summary of the Major Findings}

The following summary provides data and analysis relating to TK and TPACK obtained through administration of the instrument developed.

\subsection{Student Teacher Access to and Interest in Using ICT Resources}

Students were found to have very high levels of personal ownership of computers (99.4\%), regular access to broadband Internet (96.5\%), and surprisingly only $41.2 \%$ reported that they had access to mobile computing devices. The level of ownership of a personal computer and access to broadband Internet were similar to the 2003 student audit results [23]. For statements about interest in and perceived attitudes towards using ICT, means were calculated using a 4-point Likert scale where a mean of $1=$ Not at all; $2=$ Some extent; $3=$ Great extent; and $4=$ Very great extent. The preservice teacher education students surveyed in this study expressed strong interest in using ICT for personal purposes $(\mathrm{M}=3.06)$; strong interest in using ICT for teaching and learning purposes $(\mathrm{M}=3.25)$; extensive use of ICT for personal purposes $(\mathrm{M}=$ 3.01); a moderate level of use of ICT for teaching and learning purposes $(\mathrm{M}=2.68)$; and a strong belief that computers can improve student-learning outcomes $(\mathrm{M}=3.19)$. A Pearson Chi-square test of significance indicated no significant difference between the two universities in this study. Interestingly, a lower mean was obtained for the extent that the pre-service teachers actually use ICT for teaching and learning purposes in comparison to their belief in the value of ICT to improve student learning outcomes. The lower mean for use of ICT for teaching and learning purposes might be explained either by limited opportunities to integrate ICT when students are at practicum, or the fact that these respondents are pre-service teachers and have had limited opportunities to use ICT for teaching and learning with students. For both inferences, it appears that, for these teacher education students, there is limited evidence of TPACK capabilities. 


\subsection{Technological Knowledge (TK)}

To measure students' perception of their Technological Knowledge (TK) six items were framed as Koehler and Mishra [6] indicate that TK enables teachers to understand information technology, apply it properly, identify useful technologies, and continually adapt to changes in technology. Unlike the findings reported by Terpstra [21] that the students she studied had sound levels of TK, none of the items resulted in a high level (mean $>3$ ) of perceived competence from the pre-service teachers and, disturbingly, more than $10 \%$ of them responded that they had no competence at all with keeping informed about new digital technologies or about being able to solve their own technical problems (Items 3 and 4).

Table 4. Technological Knowledge (TK) - Perceived competence with digital technologies $(\mathrm{N}=345)$

\begin{tabular}{|l|c|c|}
\hline \multicolumn{1}{|c|}{ Technology Knowledge (TK) - Digital Technologies } & $\begin{array}{c}\text { Mean } \\
\text { (SD) }\end{array}$ & $\begin{array}{c}\text { \% No } \\
\text { Competence }\end{array}$ \\
\hline 1 I am comfortable using digital technologies. & $\begin{array}{c}2.76 \\
(.96)\end{array}$ & 2.9 \\
& $\begin{array}{c}2.64 \\
(.98)\end{array}$ & 5.2 \\
\hline 2 I learn about new digital technologies easily. & $\begin{array}{l}2.28 \\
(.99)\end{array}$ & 14.8 \\
\hline 3 I keep informed about new digital technologies. & $\begin{array}{l}2.18 \\
(.95)\end{array}$ & 16.2 \\
\hline 4 I know how to solve my own technical problems. & $\begin{array}{l}2.61 \\
(.98)\end{array}$ & 7.2 \\
\hline 5 I have the technological skills I need to use digital technologies to & $\begin{array}{l}2.48 \\
\text { achieve personal goals. }\end{array}$ & 7.0 \\
\hline 6 I have the technological skills I need to use digital technologies to & & \\
achieve professional (teaching and learning) goals. & \\
\hline
\end{tabular}

Further items asked respondents to indicate their perceived competence in using various ICT applications. Comparisons with the 2003 audit data were able to be made for Items 1 to 14 inclusive, but additional items were added to reflect new applications available since 2003. These included Web 2.0 and social networking technologies, online learning, online publishing, accessing learning objects, and creating learning objects. Despite the assumption that social networking (e.g. Facebook), online learning (all students are expected to use Blackboard in their studies), and online publishing (e.g. blogging) might be used frequently by these students, the findings did not support these assumptions.

The low perceptions of competence in using learning objects was also concerning, and this suggests that for many of these students they will not be taking advantage of the significant resources available. The applications which the students perceived that they were most competent in using were word processing, presentation software, email, web browsers, and web searching, though these were not significantly stronger than the levels of perceived competence reported by students in the 2003 audit. These findings suggest that the teacher education programs might have tended to assume that students now had higher levels of TK through more pervasive access to digital 
technologies and applications. However, that assumption is not supported beyond a limited range of applications. The implications for TPACK are profound, as insufficient TK is likely to mean limited TPK, TCK, and TPACK.

Table 5. Technological Knowledge (TK) - Perceived competence with ICT applications

\begin{tabular}{|c|c|c|c|c|c|}
\hline \multirow{2}{*}{\multicolumn{2}{|c|}{$\begin{array}{c} \\
\text { Technology Knowledge } \\
\text { ICT Software Applications } \\
\text { (Examples of Software) }\end{array}$}} & \multicolumn{2}{|c|}{$\begin{array}{c}2009 \\
(\mathrm{~N}=345)\end{array}$} & \multicolumn{2}{|c|}{$\begin{array}{c}2003 \\
(\mathrm{~N}=285)\end{array}$} \\
\hline & & $\begin{array}{c}\text { Mean } \\
\text { (SD) }\end{array}$ & $\begin{array}{c}\% \\
\text { No } \\
\text { Competence } \\
\end{array}$ & $\begin{array}{l}\text { Mean } \\
\text { (SD) }\end{array}$ & $\begin{array}{c}\% \\
\text { No } \\
\text { Competence } \\
\end{array}$ \\
\hline 1 & $\begin{array}{l}\text { Word Processing (e.g. Microsoft } \\
\text { Word) }\end{array}$ & $\begin{array}{l}3.51 \\
(.89) \\
\end{array}$ & .6 & $\begin{array}{l}3.61 \\
(.56)\end{array}$ & .4 \\
\hline 2 & $\begin{array}{l}\text { Desktop Publishing (e.g. Microsoft } \\
\text { Publisher) }\end{array}$ & $\begin{array}{c}2.47 \\
(1.11)\end{array}$ & 16.8 & $\begin{array}{l}2.70 \\
(.99)\end{array}$ & 10.9 \\
\hline 3 & $\begin{array}{l}\text { Presentation Software (e.g. } \\
\text { Microsoft Power Point) }\end{array}$ & $\begin{array}{l}3.22 \\
(.94)\end{array}$ & 1.2 & $\begin{array}{l}3.01 \\
(.92)\end{array}$ & 6.3 \\
\hline 4 & Spreadsheets (e.g. Microsoft Excel) & $\begin{array}{c}2.66 \\
(1.05) \\
\end{array}$ & 8.7 & $\begin{array}{l}2.56 \\
(.88) \\
\end{array}$ & 9.5 \\
\hline 5 & $\begin{array}{l}\text { Databases (e.g. Microsoft Access, } \\
\text { Filemaker) }\end{array}$ & $\begin{array}{l}1.85 \\
(.97)\end{array}$ & 37.1 & $\begin{array}{l}2.06 \\
(.89)\end{array}$ & 27.4 \\
\hline 6 & $\begin{array}{l}\text { Graphics creation and/or editing } \\
\text { (e.g. Paint Shop Pro, Adobe } \\
\text { Photoshop) }\end{array}$ & $\begin{array}{l}2.03 \\
(.97)\end{array}$ & 26.7 & $\begin{array}{c}2.19 \\
(1.00)\end{array}$ & 27.4 \\
\hline 7 & $\begin{array}{l}\text { Digital image capture (e.g. by } \\
\text { Digital camera, scanning) }\end{array}$ & $\begin{array}{c}2.92 \\
(1.07)\end{array}$ & 5.8 & $\begin{array}{l}2.35 \\
(1.04)\end{array}$ & 23.9 \\
\hline 8 & $\begin{array}{l}\text { Multimedia Development and } \\
\text { Authoring } \\
\text { (e.g. Macromedia Director, Flash) }\end{array}$ & $\begin{array}{l}1.59 \\
(.89)\end{array}$ & 52.8 & $\begin{array}{l}1.82 \\
(.89)\end{array}$ & 42.1 \\
\hline 9 & $\begin{array}{l}\text { Visual Thinking Software (e.g. } \\
\text { Inspiration, Kidspiration, CMap) }\end{array}$ & $\begin{array}{l}1.50 \\
(.89)\end{array}$ & 61.2 & $\begin{array}{l}1.52 \\
(.87) \\
\end{array}$ & 65.3 \\
\hline 10 & $\begin{array}{l}\text { Digital Video Editing (e.g. iMovie, } \\
\text { Adobe Premiere, MovieMaker) }\end{array}$ & $\begin{array}{c}1.86 \\
(1.06)\end{array}$ & 42.3 & $\begin{array}{l}1.48 \\
(.87)\end{array}$ & 65.6 \\
\hline 11 & $\begin{array}{l}\text { Email (e.g. Microsoft Outlook, } \\
\text { Gmail, Lotus) }\end{array}$ & $\begin{array}{l}3.36 \\
(.97)\end{array}$ & 2.0 & $\begin{array}{l}3.33 \\
(.90)\end{array}$ & 4.2 \\
\hline 12 & $\begin{array}{l}\text { Web Browsers (e.g. Internet } \\
\text { Explorer, Netscape, Safari, Firefox) }\end{array}$ & $\begin{array}{l}3.38 \\
(.94)\end{array}$ & 1.2 & $\begin{array}{l}3.42 \\
(.88)\end{array}$ & 2.8 \\
\hline 13 & Web Searching (e.g. Google) & $\begin{array}{l}3.50 \\
(.89)\end{array}$ & .3 & $\begin{array}{l}3.45 \\
(.78)\end{array}$ & 1.1 \\
\hline 14 & $\begin{array}{l}\text { Web Page Development (e.g. } \\
\text { Macromedia Dreamweaver) }\end{array}$ & $\begin{array}{c}1.73 \\
(1.01) \\
\end{array}$ & 49.6 & $\begin{array}{c}1.92 \\
(1.00) \\
\end{array}$ & 38.9 \\
\hline 15 & $\begin{array}{l}\text { Web } 2.0 \text { and Social Networking } \\
\text { (e.g. Facebook, MySpace, Flickr, } \\
\text { Twitter, YouTube, Nings) }\end{array}$ & $\begin{array}{c}2.90 \\
(1.12)\end{array}$ & 9.6 & NA & NA \\
\hline 16 & Online learning (e.g. Blackboard) & $\begin{array}{c}2.24 \\
(1.14)\end{array}$ & 27.8 & NA & NA \\
\hline 17 & $\begin{array}{l}\text { Online publishing (e.g. Blogging, } \\
\text { Podcasts, YouTube) }\end{array}$ & $\begin{array}{c}2.27 \\
(1.06) \\
\end{array}$ & 20 & NA & NA \\
\hline 18 & $\begin{array}{l}\text { Access repositories of reusable } \\
\text { learning objects }\end{array}$ & $\begin{array}{l}1.88 \\
(1.0)\end{array}$ & 36.8 & NA & NA \\
\hline 19 & Create reusable learning objects & $\begin{array}{c}1.87 \\
(1.02)\end{array}$ & 38.6 & NA & NA \\
\hline
\end{tabular}

NB. NA = Not Available in the 2003 Audit Instrument. 


\subsection{Technological Pedagogical Content Knowledge (TPACK)}

TPACK, as conceptualised by Koehler and Mishra [6], refers to the knowledge that emerges from the interaction of a teacher's content, pedagogy, and technology knowledge bases. They [6] note that Professional standards for teachers now have increased expectations for teachers to demonstrate an understanding of the complex interplay between these three key knowledge bases and how they are interpreted in specific

Table 6. TPACK - Perceived confidence to integrate ICT into student learning

\begin{tabular}{|c|c|c|}
\hline In my class, I could support students' use of ICT to: & $\begin{array}{c}\text { Mean } \\
\text { (SD) }\end{array}$ & $\begin{array}{c}\% \text { No / } \\
\text { Limited } \\
\text { Confidence }\end{array}$ \\
\hline $\begin{array}{ll}1.1 & \begin{array}{l}\text { acquire the knowledge, skills, abilities, and attitudes to deal with } \\
\text { ongoing technological change. }\end{array}\end{array}$ & $\begin{array}{l}2.48 \\
(.99)\end{array}$ & 38.8 \\
\hline develop functional competencies in a specified curriculum area. & $\begin{array}{l}2.57 \\
(.97)\end{array}$ & 34.8 \\
\hline synthesize their knowledge. & $\begin{array}{l}2.58 \\
(.98)\end{array}$ & 32.2 \\
\hline $\begin{array}{ll}1.4 & \begin{array}{l}\text { actively construct their own knowledge in collaboration with their } \\
\text { peers and others. }\end{array}\end{array}$ & $\begin{array}{c}2.61 \\
(1.00)\end{array}$ & 30.8 \\
\hline actively construct knowledge that integrates curriculum areas. & $\begin{array}{l}2.58 \\
(.99)\end{array}$ & 35.4 \\
\hline $\begin{array}{ll}1.6 & \begin{array}{l}\text { develop deep understanding about a topic of interest relevant to the } \\
\text { curriculum area(s) being studied. }\end{array}\end{array}$ & $\begin{array}{l}2.68 \\
(.99)\end{array}$ & 27.8 \\
\hline develop a scientific understanding of the world. & $\begin{array}{l}2.50 \\
(.99)\end{array}$ & 35.9 \\
\hline provide motivation for curriculum tasks. & $\begin{array}{l}2.74 \\
(.97)\end{array}$ & 23.2 \\
\hline $1.9 \quad$ plan and/or manage curriculum projects. & $\begin{array}{l}2.59 \\
(.99)\end{array}$ & 31.3 \\
\hline 1.10 integrate different media to create appropriate products. & $\begin{array}{c}2.47 \\
(1.05)\end{array}$ & 39.1 \\
\hline 1.11 engage in sustained involvement with curriculum activities. & $\begin{array}{l}2.53 \\
(.98)\end{array}$ & 35 \\
\hline 1.12 support elements of the learning process. & $\begin{array}{l}2.70 \\
(.97)\end{array}$ & 25.2 \\
\hline 1.13 demonstrate what they have learned. & $\begin{array}{l}2.75 \\
(.99)\end{array}$ & 22.3 \\
\hline 1.14 undertake formative and/or summative assessment. & $\begin{array}{l}2.68 \\
(.99)\end{array}$ & 28.4 \\
\hline $\begin{array}{ll}2.1 & \begin{array}{l}\text { acquire awareness of the global implications of ICT-based } \\
\text { technologies on society. }\end{array}\end{array}$ & $\begin{array}{c}2.43 \\
(1.02)\end{array}$ & 41.7 \\
\hline $2.2 \quad$ gain intercultural understanding. & $\begin{array}{c}2.55 \\
(1.00)\end{array}$ & 33.6 \\
\hline 2.3 critically evaluate their own and society's values. & $\begin{array}{l}2.50 \\
(.99)\end{array}$ & 38.2 \\
\hline communicate with others locally and globally. & $\begin{array}{c}2.84 \\
(1.04)\end{array}$ & 20.8 \\
\hline $\begin{array}{ll}2.5 & \text { engage in independent learning through access to education at a } \\
\text { time, place, and pace of their own choosing. }\end{array}$ & $\begin{array}{l}2.65 \\
(.95)\end{array}$ & 30.4 \\
\hline 2.6 understand and participate in the changing knowledge economy. & $\begin{array}{l}2.42 \\
(.96)\end{array}$ & 41.8 \\
\hline
\end{tabular}


teaching and learning contexts. In developing the instrument to measure the preservice teachers' TPACK in this study, the statistically robust, validated 20 item Learning with ICT: Measuring ICT Use in the Curriculum instrument [18] [25], was incorporated into this survey. That instrument has been shown to contain two strong factors. The first factor is comprised of 14 items that define student use of ICT as a tool for the development of ICT-related skills and the enhancement of curriculum learning outcomes $(\alpha=0.94)$. The second factor comprised 6 items that define ICT use as an integral component of reforms that transform what students learn and how school is structured and organised $(\alpha=0.86)$. This instrument utilises the theoretical constructs described in Good Practice and Leadership in the Use of ICT in Schools [26] and The Queensland School Reform Longitudinal Study [27] when defining ICT curriculum integration. Each of the items asks teachers to rate how their students use ICT for learning rather than how they use ICT. Because the instrument describes how students use ICT for learning as a consequence of how teachers integrate ICT into the curriculum, we contend that the 20 items measure teachers' TPACK as described by its underpinning theoretical constructs.

Overall, as shown in Table 6, the means and the percentage of preservice teacher education students reporting little or no confidence to integrate ICT into student learning in relation to the statements do not convincingly portray a story of strong TPACK capabilities. With little or confidence reported by $38.8 \%$ of the students to "acquire the knowledge, skills, abilities, and attitudes to deal with ongoing technological change" does not reflect personal and professional confidence in dealing with the technological changes one might reasonably expect will occur throughout the next 3050 years of their careers. Similarly, 2 out of every 5 students surveyed indicated that they had little or no confidence in being able to "understand and participate in the changing knowledge economy".

When the generally low levels of TK confidence, with the exception of a limited range of applications, is also taken into account, it appears that those low levels of TK might be influential in these low levels of TPACK confidence.

\section{Conclusion and Implications for Preservice Teacher Education Programs}

The key implication and key message which has emerged from this study is that we need to urgently develop a greater understanding and strengthen the use of TPACK as a shared language among teacher educators and their preservice teacher education students. The findings reported here strongly suggest that assumptions that preservice teacher education students have strong TK needs to be made problematic. We need to audit these students early and develop students' TK confidence and competence throughout their teacher education programs as an essential set of knowledges needed upon which TPACK capabilities can be built.

This paper has highlighted the potential role which the TPACK conceptualisation can make to informing preservice teacher education programs which have tended to be largely informed by PCK. We have argued that PCK is no longer adequate for learning and teaching in the 21st Century. The paper also made a significant contribution through the development of an instrument which proved to be effective in 
measuring aspects of TPACK capabilities. The data reported illustrated that, apart from a limited range of ICT applications, the students studied have inadequate levels of TK confidence. Those limited levels of TK confidence were found to translate into limited TPACK capabilities to integrate ICT for curriculum applications.

We need to encourage the implementation of strategies to better prepare future teachers for learning and teaching in the 21 st Century. To achieve this, we believe that we need a better, shared understanding of TPACK to inform teacher education courses and programs, to measure preservice teacher education students' TPACK capabilities throughout their program of study. To enable this, TPACK instruments, such as the instrument referred to in this study, need to be developed which draw upon research and evidence-based approaches.

\section{References}

1. Shulman, L.S.: Those who understand: Knowledge growth in teaching. In: Educational Researcher, AERA Presidential Address, pp. 4-14 (February 1986)

2. Shulman, L.S.: Knowledge and teaching: Foundations of the new reform. Harvard Educational Review 57, 1-22 (1987)

3. Mishra, P., Koehler, M.: Technological pedagogical Content Knowledge: A framework for teacher knowledge. Teachers College Record 108(6), 1017-1054 (2006)

4. AACTE Committee on Innovation and Technology. Handbook of Pedagogical Content Knowledge (TPCK) for Educators. Routledge/Taylor \& Francis Group, New York (2008)

5. Koehler, M.J., Mishra, P., Yahya, K.: Tracing the development of teacher knowledge in a design seminar: Integrating content, pedagogy and technology. Computers \& Education 49, 740-762 (2007)

6. Koehler, M., Mishra, P.: Introducing TPCK. In AACTE Committee on Innovation and Technology. In: Handbook of Pedagogical Content Knowledge (TPCK) for Educators. Routledge/Taylor \& Francis Group, New York (2008)

7. Queensland College of Teachers. Professional Standards for Queensland Teachers, Graduate level (2009), http://www.qct.edu.au/standards/documents / PSQT_GradLeve1_v3_Web.pdf

8. Jamieson-Proctor, R., Finger, G., Albion, P.: Auditing the TPACK Capabilities of Final Year Teacher Education Students: Are They Ready for the 21st Century? Paper presented at the Australian Computers in Education Digital Diversity Conference 2010, Melbourne, Australia, April 6-9 (2010)

9. Masters, G.N.: A Shared Challenge: Improving Literacy, Numeracy and Science Learning in Queensland Primary Schools. ACER Press, Camberwell (2009)

10. Australian Labor Party. Assessment and teaching of 21 st century skills, Media Statement, Australian Labor Party (2009), http://www.alp.org.au/media/0609/ msed090.php

11. McGaw, B.: Cited in News Release: Cisco, Intel and Microsoft collaborate to improve education assessments (2009), http://www.atc21s.org/Assets?Files/ de10c023-ead5-4ccf-8a08-cbb273bb14fb, pdf

12. Finger, G.: Education Under the Microscope How competitive is Australia? Educational Technology Solutions (33), 44-48 (2009)

13. Mishra, P., Koehler, M.: Introducing TPCK. In: AACTE Committee on Innovation and Technology (ed.). Handbook of Technological Pedagogical Content Knowledge (TPCK) for Educators. Routledge/Taylor \& Francis Group, New York (2008) 
14. Lee, M., Gaffney, M.: Leading a Digital School, Camberwell, Victoria

15. Newhouse, P., Clarkson, B., Trinidad, S.: A framework for leading school change in using ICT'. In: Trinidad, S., Pearson, J. (eds.) Using ICT in education: Leadership, Change and Models of Best Practice, pp. 148-164. Pearson Education Asia, Singapore (2005)

16. Finger, G., Jamieson-Proctor, R.: Teacher Readiness: TPACK capabilities and redesigning working conditions. In: Lee, M., Finger, G. (eds.) Developing a Networked School Community: A Guide to Realising the Vision. ACER Press, Camberwell (2010)

17. Albion, P.: Graduating Teachers' Dispositions for Integrating Information and Communications Technologies into their Teaching. In: Crawford, C., et al. (eds.) Proceedings of the Society for Information Technology and Teacher Education International Conference 2003, pp. 1592-1599. Association for the Advancement for Computing in Education (AACE), Chesapeake (2003)

18. Jamieson-Proctor, R.M., Watson, G., Finger, G., Grimbeek, P., Burnett, P.C.: Measuring the Use of Information and Communication Technologies (ICTs) in the Classroom. Computers in the Schools 24(1/2), 167-184 (2007)

19. Jamieson-Proctor, R., Finger, G.: ACT to Improve IcT Use for Learning: A synthesis of studies of Teacher Confidence in Using ICT in two Queensland schooling systems. In: Australian Computers in Education Conference (ACEC): ACT on IcT, Canberra, September 29-October 2 (2008)

20. Sahin, I., Akturk, A.O., Schmidt, D.A.: Relationship of preservice teachers' technological pedagogical content knowledge with their vocational self-efficacy beliefs. In: Research Highlights in Technology and Teacher Education, pp. 293-301 (2009)

21. Terpstra, M.J.: Developing Technological Pedagogical Content Knowledge: Preservice Teachers' Perceptions of How They Learn to Use Educational Technology in their Teaching. Unpublished Doctor of Philosophy Dissertation, Michigan State University (2009)

22. Holmes, K.: Planning to teach with digital tools: Introducing the interactive whiteboard to pre-service secondary mathematics teachers. Australian Journal of Educational Technology 25(3), 351-365 (2009)

23. Watson, G., Jamieson-Proctor, R., Finger, G., Lang, W.T.: Auditing the ICT experiences of teacher education undergraduates. Australian Educational Computing 19, 3-10 (2004)

24. Department of Education and Training (DET). Smart Classrooms Professional Development Framework (2010), http: //education.qld.gov.au/smartclassrooms/pdframework/

25. Jamieson-Proctor, R., Watson, G., Finger, G., Grimbeek, P.M.: An external evaluation of Education Queensland's ICT Curriculum Integration Performance Measurement Instrument. Griffith University, Brisbane (2005)

26. Department of Education Training and Youth Affairs (DETYA). Good Practice and Leadership in the Use of ICT in School, edNA Online, Adelaide (2000),

http: / /www. edna. edu.au/sibling/leadingpractice

27. Lingard, B., Ladwig, J., Mills, M., Bahr, M., Chant, D., Warry, M., et al.: The Queensland school reform longitudinal study. Education Queensland, Brisbane (2001) 